\title{
Relationship between Motivation to Achieve and Professional Competence in the Performance of Elementary School Teachers
}

\author{
Mohamad Syarif Sumantri ${ }^{1} \&$ Prayuningtyas Angger Whardani ${ }^{1}$ \\ ${ }^{1}$ Study Program of Elementary Education, Universitas Negeri Jakarta, Indonesia \\ Correspondence: Mohamad Syarif Sumantri, Study Program of Elementary Education, Universitas Negeri \\ Jakarta, Indonesia. Tel: 21-489-3982. E-mail: syarifsumantri@yahoo.com
}

Received: January 15, 2017

Accepted: February 18, $2017 \quad$ Online Published: June 27, 2017

doi:10.5539/ies.v10n7p118

URL: https://doi.org/10.5539/ies.v10n7p118

\begin{abstract}
This study aims to determine the relationship between achievement motivation and professional competence with regard to the performance of teachers in public elementary schools in Central Java. The quantitative method is used in this study. The results of this study indicate that (1) there is a significant positive relationship between achievement motivation and work performance among elementary school teachers, with a correlation coefficient of 0.961 . (2) There is a significant positive relationship between the professional competence and performance of elementary school teachers, with a correlation coefficient of 0.979 . (3) There is a significant positive relationship between the achievement motivation and professional competence of teachers (considered together) and the work performance of elementary school teachers, with a correlation coefficient of 0.982 and contribution of $96.4 \%$.
\end{abstract}

Keywords: elementary school teacher job performance, motivation to achieve, professional competence

\section{Introduction}

One of the main problems contributing to the low quality of education and the need improvements in schools is the low achievement of teachers who work a variety of basic education settings. This problem is evidenced by the underdeveloped competencies of many teachers. Teachers should be able to competently facilitate the learning process; they should show the ability to plan and to foster learning and skills in personal relations, and they should also be supported by adequate facilities. Additionally, teachers need to improve their ability to teach and to master the subjects being taught. Finally, teachers must also understand the learning conditions facing their students and be able to competently create active learning activities so that they produce qualified students.

Unfortunately, efforts to improve the job performance of teachers are very difficult to implement. Existing performance data on public elementary school teachers in central java have shown that they work in minimally satisfactory working conditions and that they face problems concerning human resources. Many factors affect the job performance of teachers, including low teacher salaries, inappropriate leadership styles, facilities that do not support the learning process, and low teacher motivation. Empirical evidence shows that many teachers do not approach the task of teaching as a profession. Instead, most teachers view teaching jobs merely as a way to earn a salary every month; they do not approach the task of teaching as a career that requires one to attain a number of competencies as prerequisites to working professionally (Gultom, 2013). Minister of Education and Culture of the Republic of Indonesia stated that Indonesian education is in a state of emergency. This is clear from the fact that the average value of teacher competence in Indonesia is only 44.5. In fact, the value of teacher competency standards is 75 (Kompas, 2017). Beyond these scores, there are many other problems that must be addressed with regard to teachers. In addition to having inadequate education, teachers also lack competence. When teachers in all fields of study are tested, they are, on average, unable to answer 50 percent of the questions presented to them (Antaranews, 2013).

This study aims to obtain empirical information that will aid in determining (1) the relationship between the motivation to achieve and work performance among elementary school teachers; (2) the relationship between the professional competence of teachers and elementary school teacher job performance; and (3) the relationship between, on the one hand, the combination of the motivation to achieve and the professional competence of elementary school teachers, and, on the other hand, the job performance of elementary school teachers. 
The definition of "job performance" is derived from the definition of "performance": the fulfillment of work requirements or the results of performance (Goldhaber \& Hansen, 2008). Job performance can also be interpreted as performance. Job performance is the result of the actual performance achieved by a person and involves both the quality and quantity of a worker's achievements in performing job functions in accordance with the responsibilities given to him/her. Colquitt defines performance as "the value of the set of employee behaviors that contribute, either positively, or negatively, to organizational goal accomplishment" (Colquitt, LePine, \& Wesson, 2013). Job performance is a set of values, both positive and negative, that employees contribute for the purpose of the development of an institution. Job performance is the quantity and quality of the work completed by an individual, group or organization (Hogan \& Holland, 2003). In this case, work performance is related to the quality and quantity of work. Referring to the view of performance described above, it appears that strong work performance is the result achieved by a person who performs his or her job effectively and efficiently. According to Colquitt et al. (2013), individual performance is a function of a combination of three factors: 1) the ability, temperament, and interests of the worker; 2) the explanation of, clarity of and acceptance of the role a worker is expected to perform; and 3) a worker's level of motivation to work. More specifically, Wright and Hobfoll (2004) have stated that teacher work performance is related to teacher behavior during the activities that compose the learning process, such as how a teacher prepared a lesson plan, implemented learning activities and assessed learning outcomes.

Teachers' job performance is based on the results achieved by teachers when they perform their jobs efficiently and effectively within a certain time frame. Factors that are considered when assessing the job performance of teachers include (a) the quality of the work performed, (b) the speed with which the work is performed, (c) the accuracy of the work performed, (d) initiatives taken by the teacher in performing her work, (e) ability shown by the teacher, and (f) the establishment of communications between a teacher and her students. These factors are related to (1) mastering the details of the duties and other related learning tasks of the field, (2) acquiring the skills necessary for carrying out the task of teaching, (3) attaining mastery and broad experience in the field of duty and other related fields, (4) remaining persistent in carrying out the task of teaching, (5) maintaining physical fitness and a healthy spirituality, (6) performing one's duties effectively and efficiently, (7) working harder than the organization, unit, or institution of employment demands, (8) carrying out the task of teaching effectively, and (9) performing the task of teaching efficiently.

According to Luthans (2011), motivation is a basic psychological process. Motivation interacts with and acts in conjunction with other mediating processes and the environment. It must also be emphasized that, like other cognitive processes, motivation cannot be observed. All that can be observed is behavior. The motivation to achieve can be interpreted as a person's desire to do or perform an activity or task as well as possible in order to achieve a commendable outcome (Saeid \& Eslaminejad, 2017).

According to Awan, Noureen, and Naz (2011), motivation to achieve is the motivation that drives a person to achieve more than she has ever created or achieved before, or to achieve more than any other person has created or achieved. This means that when a person already has a desire to outperform others, that person has the motivation to achieve.

Motivation to achieve is a series of perceptions or desires that arise within a person who encourages himself to achieve more than what he has created or achieved before, or to achieve more than what others have created or achieved. Such achievement motivation can be measured by one's efforts to excel in certain groups; one's ability to embrace challenges, rational success, and a job well-done; one's passion for job situations involving personal responsibility, feedback, and a medium level of risk; and one's ability to accept personal responsibility for success.

According to Spector and de la Teja (2001), competence is a term that describes one's qualifications or abilities, whether qualitative or quantitative. Semaan and Yamazaki (2015) explained that competency is related to knowledge, skills, abilities and personality characteristics, all of which directly influence performance. Competence, according to del pro Lesorado (2011), is an underlying characteristic of individuals; it is causally related to effective and/or superior performance in a job or situation. Such competence is related to the effectiveness of that person's individual performance in a given job; it enables the individual to achieve effective, excellent or superior performance at work or in certain situations. Thus, competence is an essential characteristic of a person who has above-average ability, distinguishing her from someone who possesses only average ability.

Professional competence is the ability to master - both broadly and deeply - the learning materials that allow learners to meet the standards of competence specified in national education standards (Kunter et al., 2013). Professional competence in teachers can be defined as the skill or ability to carry out the basic tasks required of 
learning plans; skill in implementing or managing the learning process; and the ability to assess the skills required of the teaching and learning process.

Professional competence in teachers can be grouped into two categories: substantive competence and non-substantive competence. Substantive competence is defined as the ability to carry out tasks that can be observed in the planning of teaching and learning programs and in the management and implementation of the learning process; it is also part of the teacher's ability to evaluate the results of the learning process. Non-substantive competence is defined in terms of a teacher's ability to bring grounding and insight into the educational setting, as well as in terms of a teacher's personality and her contributions to the overall professional development of other teachers. Professional competence among teachers is necessary in cultivating quality education personnel, in this case other teachers. Teachers are largely responsible for the quality of education offered and for students' educational success in school. Therefore, the level of professional competence of teachers in a school sets the standard for the quality and success of education in that school.

According to Baumert and Kunter (2006) and Spector and Davidsen (2000), the professional competence of a teacher is the ability of that teacher to carry out the tasks of the teaching profession as a teacher, counselor or administrator in a class. This competence consists of (1) control of the learning materials, (2) managing the teaching and learning programs, (3) managing the class, (4) using media and other learning resources effectively, (5) controlling the cornerstone of education, (6) managing teaching and learning interactions, (7) assessing learning achievement, (8) knowing the functions and services involved in counseling, (9) identifying problems and properly administering the school, and (10) understanding and interpreting the results of research in relation to the purpose of learning.

Any individual who works at an organization is expected to achieve optimal results, i.e., to perform well. Teacher performance is influenced by the teacher's professional competence, as competent teachers are able to produce quality performance. However, some teachers who have insufficient levels of competence can still produce quality performances, while other teachers with high levels of competence are less capable of producing quality performances. Rebore (2014) stated that a teacher's performance-related skills and his or her ability to do something are two different things. Furthermore, J. Eller and S. Eller (2015) whose findings are supported by Jalali and Heidari (2016), state that the performance of teachers is the ability to carry out a task or job and that it corresponds to attitudes, knowledge, skills, and motivation. Based on the description above, the following question can be formulated: what is the relationship between achievement motivation and professional competence with regard to a teacher's job performance?

\section{Method}

Our research uses a quantitative correlation method. This technique analyzes the relationship between the two (2) independent variables (achievement motivation (X1) and professional competence (X2)) and one (1) dependent variable: elementary teachers' work performance $(\mathrm{Y})$.

The population was composed of elementary school teachers in Bekasi, west Java. The samples in this study were drawn from the three elementary schools in cluster 2 and resulted in a total of 250 respondents.

Data were collected through questionnaires on achievement motivation techniques, professional competence and the job performance of teachers.

The instrument used to measure the three variables was a Likert-scale questionnaire. The validity of the instrument analyzed the relationship score of each item with a total score (using the formula Product Moment Correlation) and instrument reliability test (using the Cronbach's Alpha formula). To test the hypothesis using the technique of Pearson product-moment correlation, SPSS 20 was used for data analyses.

The job performance of teachers is a form of learning behavior with a job-performance orientation. Instrument performance is a respondent's score consisting of 30 items, which use statements based on the following indicators: (1) planning lessons, (2) organizing the subject matter, (3) planning classroom management, (4) planned media and learning methods, (5) planned assessments of learning, (6) managing learning; organizing time, students, and facilities for learning, (7) conducting the assessment process and producing results.

Achievement motivation is a person's desire to implement behavior that better meet their needs. Respondents' achievement motivation scores were based on 30 items of statement indicators: (1) develops positive motivation among students, (2) demonstrates seriousness in teaching, (4) works hard (5) to have any hope of success, and (6) attempts to obtain high scores.

Respondents' professional competence was based on their scores on 30 items pertaining to professional competence, which reflects the ability of teachers to carry out their professional duties according to the 
dimensions of 1) understanding of knowledge learning, 2) understanding of the characteristics of the students, 3) designing learning, 4) the use of learning technology, 5) capability of assessing learning outcomes, 6) ability to develop the potential of students, 7) responsibility for students' knowledge, 8) possessing supporting knowledge about the condition of students, 9) control of learning materials, 10) ability to motivate students and 11) ability to be a role model.

The validity and reliability of the instrument were assessed based on the validity of the trial in primary schools in Jakarta, which included 60 teachers. The test results were analyzed using the relation score of the items and a total score using correlation Pearson's Product Moment, which was based on testing the validity of the instrument job performance of teachers; the test was performed on 35 items and then 30 items to ensure that the statements were valid.

The reliability of the instrument job performance of teachers is reliable according to the Cronbach's Alpha test. This item has a reliability coefficient of 0.85 on 30 items of the statement and has met the criteria of the empirical reliability coefficient, which states that an instrument is more reliable if the reliability coefficient is above 0.70 .

The validity of the instrument achievement motivation was tested. After testing 40 items, 30 items were found to be valid. For this instrument, a test reliability coefficient of 0.98 was obtained, indicating that the 30 items are reliable because they meet the criteria of general empirical reliability: a coefficient is reliable if the reliability coefficient is above 0.70 .

The validity of the instrument professional competence was tested. After testing 43 items, 33 items were found to be valid. A reliability test of professional competence was conducted, yielding a reliability coefficient of 0.97 for 33 items and indicating reliable statements.

\section{Result}

A normality test was performed to determine whether residues are normally distributed or not. Based on the test results of normality with the One-Sample Kolmogorov-Smirnov Test, process analysis prerequisite test calculations are calculated with the aid of the computer program SPSS 20, producing the following results:

Based on calculations, it can be observed in Table 1 that the value of $r$ is less than the level of $\alpha$ used (i.e., 0.05), or $0.62>0.05$. Thus, $\mathrm{H}_{0}$ is accepted. This means that the motivation to achieve has a normal distribution.

Table 1. Test for normality of motivation to achieve

\begin{tabular}{llll}
\hline \multicolumn{4}{c}{ Tests for Normality } \\
\hline & Kolmogorov-Smirnov & \\
\cline { 2 - 5 } & Statistic & Df & Sig. \\
\hline Motivation to Achieve & 0.055 & 250 & 0.62 \\
\hline
\end{tabular}

a. Lilliefors significance correction

Table 2. Test for normality of professional competence

\begin{tabular}{llll}
\hline \multicolumn{3}{c}{ Tests for Normality } \\
\cline { 2 - 4 } Kolmogorov-Smirnov $^{\mathrm{a}}$ & Sig. \\
\hline Statistic & Df & .064 \\
\hline Professional Competence .055 & 250 & \\
\hline
\end{tabular}

a. Lilliefors significance correction

Based on the calculations, it can be seen in Table 2 that the value of $r$ is less than the level of $\alpha$ used (i.e., 0.05), or $0.064>0.05$. Thus, $\mathrm{H}_{0}$ is accepted. This means that professional competence is normally distributed. The summary of the test results' correlation coefficients can be observed in Table 3 below: 
Table 3. Summary of test results' correlation coefficients

\begin{tabular}{|c|c|c|c|c|c|c|c|c|}
\hline Variable & $\mathrm{R}$ & R Square & $\begin{array}{l}\text { Adjusted R } \\
\text { Square }\end{array}$ & $\begin{array}{l}\text { Std. Error of the } \\
\text { Estimate }\end{array}$ & $\begin{array}{c}\mathrm{F} \\
\text { Change }\end{array}$ & df1 & $\mathrm{df} 2$ & $\begin{array}{l}\text { Sig. F } \\
\text { Change }\end{array}$ \\
\hline $\mathrm{X}_{1}$ to $\mathrm{Y}$ & 0,961 & 0,924 & 0,924 & 7,532 & 3030,062 & 1 & 248 &, 000 \\
\hline $\mathrm{X}_{2}$ to $\mathrm{Y}$ & 0,979 & 0,958 & 0,958 & 5,605 & 5672,086 & 1 & 248 &, 000 \\
\hline$X_{1}$ and $X_{2 \text { to }} Y$ & 0,982 & 0,964 & 0,966 & 5,029 & 3553,000 & 2 & 247 &, 000 \\
\hline
\end{tabular}

Table 4. Linear equations and significance coefficients of the regression equation $\mathrm{X} 1$ to $\mathrm{Y}$

\begin{tabular}{|c|c|c|c|c|c|c|}
\hline \multicolumn{7}{|c|}{ Coefficients $^{\mathrm{a}}$} \\
\hline & \multirow[t]{2}{*}{ Model } & \multicolumn{2}{|c|}{ Unstandardized Coefficients } & $\begin{array}{c}\text { Standardized } \\
\text { Coefficients }\end{array}$ & \multirow[t]{2}{*}{$\mathrm{T}$} & \multirow[t]{2}{*}{ Sig. } \\
\hline & & $\mathrm{B}$ & Std. Error & Beta & & \\
\hline \multirow{2}{*}{1} & (Constant) & 5,204 & 2,021 & & 2,574 & ,0113 \\
\hline & Motivations of Achieve & ,969 &, 018 & ,961 & 54,495 &, 000 \\
\hline
\end{tabular}

a. Dependent Variable: Elementary School Teacher Job Performance

Table 5. Linear equations and significance coefficients of the regression equation $\mathrm{X} 2$ to $\mathrm{Y}$

\begin{tabular}{|c|c|c|c|c|c|c|}
\hline \multicolumn{7}{|c|}{ Coefficients $^{\mathrm{a}}$} \\
\hline & \multirow[t]{2}{*}{ Model } & \multicolumn{2}{|c|}{ Unstandardized Coefficients } & $\begin{array}{l}\text { Standardized } \\
\text { Coefficients }\end{array}$ & \multirow[t]{2}{*}{$\mathrm{t}$} & \multirow[t]{2}{*}{ Sig. } \\
\hline & & B & Std. Error & Beta & & \\
\hline \multirow{2}{*}{1} & (Constant) & 2,573 & 1,513 & & 1,701 & ,090 \\
\hline & Professional Competence & ,985 & 013 &, 979 & 74,845 & 000 \\
\hline
\end{tabular}

a. Dependent Variable: Elementary School Teacher_Job Performance

Table 6. Linear equations and significance coefficients of the regression equation $\mathrm{X} 1$ and $\mathrm{X} 2$ to $\mathrm{Y}$

\begin{tabular}{|c|c|c|c|c|c|c|}
\hline \multicolumn{7}{|c|}{ Coefficients $^{\mathrm{a}}$} \\
\hline & \multirow[t]{2}{*}{ Model } & \multicolumn{2}{|c|}{ Unstandardized Coefficients } & $\begin{array}{c}\text { Standardized } \\
\text { Coefficients }\end{array}$ & \multirow[t]{2}{*}{$\mathrm{t}$} & \multirow[t]{2}{*}{ Sig. } \\
\hline & & $\mathrm{B}$ & Std. Error & Beta & & \\
\hline \multirow{3}{*}{1} & (Constant) & 1,596 & 1,369 & &, 884 & ,378 \\
\hline & Motivations of Achieve & ,286 &, 039 &, 305 & 7,812 &, 000 \\
\hline & Professional Competence &, 351 &, 039 &, 687 & 17,587 &, 000 \\
\hline
\end{tabular}

a. Dependent Variable: Elementary School Teacher Job Performance

\section{Discussion and Conclusion}

The first hypothesis showed a correlation coefficient of $r=0.961$ as seen in Table 3 . The result of this calculation is then compared with the $\mathrm{r}$ table, with $\mathrm{N}=250$ and a significance level of 0.05 , resulting in the following table value for $r$ : $r$ table $=0.113$. In this case, $r$ calculation $>r$ table or $0.560>0.113$. Thus, the null hypothesis $($ Ho) is rejected. The results of the significance test of the correlation obtained from a t-test proves that the correlation coefficient obtained is meaningful because $t=54.495$ as shown in Table 4 is greater than $t$ table $=0.683$, or $54.495>0.683$. From the results of hypothesis testing above, it can be concluded that the first hypothesis, which stated that there was a positive and significant relationship between motivation to achieve and teachers' job performance, proved to be true. The correlation coefficient $r=0.961$ indicates a strong relationship between variables. This is in accordance with the opinion of Kunter et al. (2013), who states that a person's need for achievement (Need for Achievement / n-Ach) will encourage that person to develop creativity and to use all her energy to pursue optimal achievement and to achieve an optimal outcome.

The second hypothesis states that there is a significant positive relationship between the teacher's professional competence and job performance. A correlation analysis technique was used to test this hypothesis. Based on calculations from the product moment formula, a correlation coefficient of $r=0.979$ was obtained can be seen in Table 3. The result of this calculation was then compared with the $r$ table value, with $\mathrm{N}=250$ and a significance 
level of 0.05 , resulting in a value of $r$ table $=0.113$. In this case, $r$ calculation $>r$ table, or $0.979>0.113$. Thus, the null hypothesis $(\mathrm{Ho})$ is rejected. The test of significance for this correlation, obtained by conducting a t-test, shows that the correlation coefficient obtained is meaningful because $t=74.845$ as shown in Table 5 is greater than $\mathrm{t}$ table $=0.683$, or $74.845>0.683$. From the results of hypothesis testing reported above, it can be concluded that the second hypothesis, which stated that there was a significant positive relationship between a teacher's professional competence and job performance, proved to be true. These findings are in accordance with the opinion of Baumert and Kunter (2006) and Cheetham and Chivers (1998), who state that competence is a characteristic that makes someone stand out and guides her behavior and thinking under all circumstances, that competence is sustainable over a long period of time and can result in the successful performance of one's work and that competence will often manifest itself in one's thoughts, attitudes and behavior. The level of professional competence a teacher attains can influence that teacher's job performance. The magnitude of the correlation coefficient, $r=0.979$, shows a high level of correlation between variables.

The third hypothesis states that there is a positive and significant relationship between motivation to achieve and professional competence, considered together, and the job performance of elementary school teachers. A correlation technique and multiple regression analysis were used to test this hypothesis. Based on calculations according to the product moment formula, a correlation coefficient of $r=0.982$ was obtained as shown in Table 3 . The result of this calculation was then compared with the table value of $r$, where $\mathrm{N}=250$ and the significance level $=0.05$, resulting in a value of the $r$ table $=0.113$. In this case $r$ calculation $>r$ table, or $0.982>0.113$. Thus, the null hypothesis $(\mathrm{Ho})$ is rejected. The results of a significance test show that $\mathrm{F}=3881.22$, and the $\mathrm{F}$ calculation is greater than the $\mathrm{F}$ table, or $3881.22>3$. This result shows that the model of the relationship between $\mathrm{X} 1$ and $\mathrm{X} 2$ with $\mathrm{Y}$ is statistically significant and that the regression obtained is meaningful where the multiple regression equation, or model of the relationship between the variables $\mathrm{X} 1$ and $\mathrm{X} 2$ to $\mathrm{Y}$, is $\mathrm{Y}=1.596+0.286 \mathrm{X} 1+0.351$ $\mathrm{X} 2$ and is statistically significant as shown in table 6 . From the results of the hypothesis testing described above, it can be concluded that the third hypothesis, stating that there is a positive and significant relationship between elementary school teachers' motivation to achieve and professional competence (considered together) and job performance, proved to be true. These findings correspond with the opinions of Mulder (2014) and Lim-Teo, Low, Wong, and Chong (2008), who explain that individual performance is a function of a combination of three factors: 1) the ability, temperament, and interests of the worker; 2) the clarity of and acceptance of the explanation of the role of the worker; and 3) the level of work motivation. Job performance is optimal if a teacher has the motivation and skills that match the job and if a teacher works under conditions that allow her to do her best work. Of course, teachers who have a positive attitude toward work will have good perceptions of their job, higher satisfaction with their job, and high levels of motivation to achieve in their job. These attributes, in turn, will produce a teacher who is able to work in a professional manner. Not surprisingly, the more professional a teacher is, the better her job performance will be. Thus, the relationship of motivation to achieve and professional competence, considered together, with job performance shows that improving these two variables together results in improved performance among elementary school teachers.

The correlation coefficient of 0.982 shows that the relationship between variables is quite high, while the regression equation above means that if motivation to achieve and teachers' professional competence increase, then teachers' job performance tends to increase at the rate of $0.286 *$ achievement motivation $+0.351 *$ professional competence, from a constant base of 1.596.

Table 7. Relative Contribution (RC) and Effective Contribution (EC)

\begin{tabular}{|c|c|c|c|c|c|}
\hline No & $\mathrm{X}$ & $\mathrm{Y}$ & (RC) $\%$ & (EC) $\%$ & Predictor's Contribution \\
\hline 1 & (X1) & \multirow{3}{*}{$(\mathrm{Y})$} & 30 & 29 & 59 \\
\hline 2 & $(\mathrm{X} 2)$ & & 36 & 35 & 71 \\
\hline 3 & $(\mathrm{X} 1)$ and $(\mathrm{X} 2)$ & & 100 & 96 & \\
\hline
\end{tabular}

Based on the results of our research, it can be concluded that, first, there was a significant positive relationship between motivation to achieve and work performance among elementary school teachers. The first independent variable had a relative contribution of $30 \%$ and an effective contribution of $29 \%$, with a total contribution of $59 \%$ of the predictors of teachers' job performance as shown in Table 7 . This meant that the more strongly teachers felt a motivation to achieve, the better their performance. Second, there was a significant positive relationship between professional competence and job performance among elementary school teachers. The second independent variable had a relative contribution of $25 \%$ and an effective contribution of $70 \%$, with a total 
contribution of $95 \%$ of the predictors of teachers' job performance in shaping the linear regression between independent variables and the dependent variable as shown in Table 7. These findings correspond with the opinion of Cheetham and Chivers (1998), who state that professional competence had a direct relationship with the performance of elementary school teachers; the stronger the professional competencies possessed by an elementary school teacher, the better the performance of that teacher (Li, Lee, \& Solmon, 2005). Third, there was a significant positive relationship between the motivation to achieve and the professional competence of teachers (considered together) and teachers' job performance. Together, motivation to achieve and teachers' professional competence had a relative contribution of $100 \%$ and an effective contribution of $96 \%$ to the job performance of elementary school teachers as shown in Table 7. This meant that motivation to achieve and professional competence contributed strongly to the performance of elementary school teachers. Knowing that the variables of motivation to achieve and professional competence provide an effective contribution of $96 \%$ to the performance of teachers provides significant insight into how to best focus efforts to improve teachers' job performance.

\section{References}

Antaranews. (2013). Ministry of education and culture recognizes the quality of teachers remains low. Retrieved from http://www.antaranews.com/berita/397722/kemdikbud-akui-kualitas-guru-masih-rendah

Awan, R., Noureen, G., \& Naz, A. (2011). A study of relationship between achievement motivation, academic self concept and achievement in English and mathematics at secondary level. International Education Studies, 4, 72-79. https://doi.org/10.5539/ies.v4n3p72

Baumert, J., \& Kunter, M. (2006). The COACTIV model of teachers' professional competence. In M. Kunter, J. Baumert, W. Blum, U. Klusmann, S. Krauss, \& M. Neubrand (Eds.), Cognitive activation in the mathematics classroom and professional competence of teachers: Results from the COACTIV project (pp. 25-48). Boston, MA: Springer US.

Cheetham, G., \& Chivers, G. (1998). The reflective (and competent) practitioner: A model of professional competence which seeks to harmonise the reflective practitioner and competence-based approaches. Journal of European Industrial Training, 22, 267-276. https://doi.org/10.1108/03090599810230678

Colquitt, J., LePine, J., \& Wesson, M. (2013). Organizational behavior: Improving performance and commitment in the workplace (4th ed.). New York, NY: McGraw-Hill, Companies, Inc.

Del pro Lesorado, F. (2011). Standars of professional competencies required of teachers, general directorate of education, vocational training and learning innovation. Year 2010-2011 (pp. 12-49). Retrieved from http://cfieleon.centros.educa.jcyl.es/sitio/upload/modelo_competencias_profesionales_profesorado\%20_tra ducido.pdf

Eller, J. F., \& Eller, S. A. (2015). Score to soar: Moving teachers from evaluation to professional growth. New York, NY: Solution Tree Press.

Goldhaber, D., \& Hansen, M. (2008). Assessing the potential of using value-added estimates of teacher job performance for making tenure decisions. Washington, DC: National Center for Analysis of Longitudinal Data in Education Research. The Urban Institute. https://doi.org/10.1037/e722392011-001

Gultom, S. (2013). The low quality of the teacher-in-Indonesia. Retrieved from http://www.sekolahdasar.net/2013/09/kualitas-guru-di-indonesia-masih-rendah.html

Hogan, J., \& Holland, B. (2003). Using theory to evaluate personality and job-performance relations: A socioanalytic perspective. Journal of Applied Psychology, 88, 100-112. https://doi.org/10.1037/0021-9010.88.1.100

Jalali, Z., \& Heidari, A. (2016). The relationship between happiness, subjective well-being, creativity and job performance of primary school teachers in Ramhormoz city. International Education Studies, 9, 45. https://doi.org/10.5539/ies.v9n6p45

Kompas. (2017). Indonesia education emergency. Retrieved from http://edukasi.kompas.com/read/2014/12/01/ 13455441/anies.baswedan.sebut.pendidikan.indonesia.gawat.darurat

Kunter, M., Klusmann, U., Baumert, J., Richter, D., Voss, T., \& Hachfeld, A. (2013). Professional competence of teachers: Effects on instructional quality and student development. Journal of Educational Psychology, 105, 805-820. https://doi.org/10.1037/a0032583

Li, W., Lee, A. M., \& Solmon, M. A. (2005). Relationships among dispositional ability conceptions, intrinsic 
motivation, perceived competence, experience, and performance. Journal of Teaching in Physical Education, 24, 51-65. https://doi.org/10.1123/jtpe.24.1.51

Lim-Teo, S. K., Low, E. L., Wong, A. F., \& Chong, S. (2008). Motivation, competence, and confidence to teach-an exploratory study of the impact of an initial teacher preparation (ITP) programme on beginning primary school teachers. KEDI Journal of Educational Policy, 5, 41-61.

Luthans, F. (2011). Organizational behavior: An evidence-based approach (12th ed.). New York, NY: McGraw-Hill.

Mulder, M. (2014). Conceptions of professional competence. In S. Billett, C. Harteis, \& H. Gruber (Eds.), International Handbook of Research in Professional and Practice-based Learning (pp. 107-137). Dordrecht: Springer. https://doi.org/10.1007/978-94-017-8902-8_5

Rebore, R. W. (2014). Human resources administration in education: A management approach. New York, NY: Pearson Education.

Saeid, N., \& Eslaminejad, T. (2017). Relationship between student's self-directed-learning readiness and academic self-efficacy and achievement motivation in students. International Education Studies, 10, 225-233. https://doi.org/10.5539/ies.v10n1p225

Semaan, G., \& Yamazaki, K. (2015). The relationship between global competence and language learning motivation: An empirical study in critical language classrooms. Foreign Language Annals, 48, 511-520. https://doi.org/10.1111/flan.12146

Spector, J. M., \& Davidsen, P. I. (2000). Designing technology enhanced learning environments. In B. Abbey (Ed.), Instructional and cognitive impacts of Web-based education (pp. 246-257). London: Idea Group Publishing.

Spector, J. M., \& De la Teja, I. (2001). Competencies for online teaching. ERIC Digest, p. 2. https://doi.org/10.4018/978-1-878289-59-9.ch016

Wright, T. A., \& Hobfoll, S. E. (2004). Commitment, psychological well-being and job performance: An examination of conservation of resources (COR) theory and job burnout. Journal of Business and Management, 9, 389-406. Retrieved from http://www.ccsenet.org/journal/index.php/ies/article/view/54962

\section{Copyrights}

Copyright for this article is retained by the author(s), with first publication rights granted to the journal.

This is an open-access article distributed under the terms and conditions of the Creative Commons Attribution license (http://creativecommons.org/licenses/by/4.0/). 